\title{
Effect of Aluminum, Nitrogen and Silicon Content on the Toughness of C-Mn Steel Weld Heat Affected Zone
}

\author{
Hongchul Jeong*, $\uparrow$ and Kyutae Han* \\ *Welding and Joining Research Group, Technical Research Laboratories, POSCO, Pohang, 37859, Korea \\ †Corresponding author : jeonghc@posco.com \\ (Received October 7, 2019 ; Revised October 25, 2019 ; Accepted November 25, 2019)
}

\begin{abstract}
In the present study, the effect of aluminum, silicon, and nitrogen content on the microstructure and toughness of the weld heat affected zone (HAZ) of tensile strength, 400-500MPa grade steels was investigated. The change in phase fraction, precipitate distribution as a function of peak temperature and cooling time were analyzed to clarify the effect of each alloying element on the microstructural changes and toughness of the weld HAZ. The optimal aluminum, nitrogen, and silicon content was determined by impact toughness and the microstructure of the simulated coarse grained heat affected zone (CGHAZ) concerning appropriate ferrite and bainite fraction, minimization of a cementite, a martensite-austenite (M-A) constituent distribution, and free nitrogen in a matrix.
\end{abstract}

Key Words : Welding, Heat affected zone, Toughness

\section{Introduction}

The principal shipbuilding and construction market requirements for steel plate have been higher strength, and wider applicability of high heat input welding for lower operating and fabrication cost, respectively. As a strength of steel and welding heat input increases, the toughness of weld heat affected zone (HAZ) of C-Mn micro alloyed steel, which determines the structural safety significantly, can be deteriorated by undesirable HAZ microstructure, and that of coarse grained heat affected zone (CGHAZ), in particular. Generally, CGHAZ microstructures of tensile strength, 400-500MPa grade steels consist of (upper) bainite, Widmanstätten ferrite, grain boundary ferrite, and undesirable martensite-austenite (M-A) constituents. The fraction of each phase which determines the toughness is directly affected by a chemical composition, a cooling rate, and a prior austenite grain size.

Effect of Al addition on the base metal and HAZ toughness has been reported several researchers in the viewpoint of a carbide precipitation ${ }^{1,2)}$, a M-A constituent formation ${ }^{1,3)}$, and a rejection of free nitrogen ${ }^{4-6)}$ as a function of $\mathrm{Al}$ content and welding heat input. Fukuda $^{1)}$ investigated the effect of $0.015 \mathrm{wt} \% \mathrm{Al}$-addition to $0.1 \mathrm{C}-0.2 \mathrm{Si}-1.4 \mathrm{Mn}-0.01 \mathrm{Ti}$ steel which showed lower crack tip opening displacement (CTOD) compare to ultra-low $\mathrm{Al}(<0.001 \mathrm{w} \%)$ steel in the submerged arc welded multi-pass heat affected zone due to the promotion of bainite and M-A constituent, rather than ferrite and cementite. Meanwhile, Xue ${ }^{2}$ et al. studied the effect of $0.04 \sim 0.2 \mathrm{wt} \% \mathrm{Al}$ addition on the cementite precipitation of $0.1 \mathrm{C}-0.5 \mathrm{Si}-1.5 \mathrm{Mn}-0.15 \mathrm{Mo}-0.5 \mathrm{Ni}-0.05 \mathrm{~V}$ steel. The authors pointed out that the mean size and number of cementite, and the prior austenite grain size decrease as $\mathrm{Al}$ content increases due to the retardation of cementite coarsening by decrease of Fe diffusion as a result of the $\mathrm{Al}$ segregation at grain boundaries. $\mathrm{Yu}^{3)} \mathrm{re}-$ ported that effect of $0.04 \sim 0.07 \mathrm{wt} \% \mathrm{Al}$ addition on the weld HAZ of $0.05 \mathrm{C}-0.2 \mathrm{Si}-1.6 \mathrm{Mn}-0.01 \mathrm{Ti}$ steel and the toughness of the CGHAZ was improved remarkably with increasing aluminum content even at high heat input of $200 \mathrm{~kJ} / \mathrm{cm}$ due to the reduction of size and volume fraction of M-A constituent. Nishio ${ }^{4)}$ and Watanabe ${ }^{5)}$ reported that toughness of the weld HAZ increases as $\mathrm{Al}$ content increases up to $0.06 \mathrm{wt} \%$ due to the reduction of solid solution nitrogen as a result of AlN precipitation 
during cooling process. Mintz ${ }^{6}$ reported that effect of $\mathrm{Al}$ content on the strength and toughness of (0.02, $0.1 \% \mathrm{C})-(10,40 \mathrm{ppm} \mathrm{N})$ steel, and concluded that HAZ toughness was increased with $0.2 \% \mathrm{Al}$ as a result of cementite refinement and rejection of free nitrogen with no significant change of the strength. As described above, all of the test reports about weld HAZ have limited to the steels containing $\mathrm{Al}$ less than $0.07 \mathrm{wt} \%{ }^{1,3-5}$ ) while the steels that contain Al higher than $0.1 \mathrm{wt} \%$ show quite good toughness ${ }^{2,6)}$ due to the various beneficial effect of $\mathrm{Al}$ addition.

In the present study, effect of $\mathrm{Al}$ content in the range of 0.02 to $0.8 \mathrm{wt} \%$ on the microstructure and toughness of the simulated weld HAZ of tensile strength, 400$500 \mathrm{MPa}$ grade steels concerning various welding heat input were investigated. Additionally, the effect of the change of $\mathrm{Si}$, and $\mathrm{N}$ content on the toughness was also studied. The change of phase fraction, M-A constituent, precipitate distribution as a function of peak temperature and cooling time were analyzed for clarifying the effect of each alloying element on the microstructural changes and toughness of the weld HAZ.

\section{Experimental Procedure}

\subsection{Test Materials}

Table 1 shows the chemical composition, yield and tensile strength, elongation of the test materials. $0.02 \sim$ $0.81 \mathrm{wt} \%$ of $\mathrm{Al}$ were added to the same base composition of $\mathrm{C}, \mathrm{Si}, \mathrm{Mn}$-alloyed steel (Numbers of materials from 1 thorough 8 ). The numbers of 9,10 , and 11, 12 materials were added to study the effect of nitrogen, and silicon content on the $0.3 \% \mathrm{Al}$ added steel (No.5 material), respectively. $15 \mathrm{~mm}$ thick test coupons were manu- factured by hot rolling process using vacuum melted ingot. The ingots were austenized for 2 hours and hotrolled with $10 \%$ thickness reduction ratio above $900{ }^{\circ} \mathrm{C}$ and cooled in the air. The yield and tensile strength of test materials were in the range of $290 \sim 420 \mathrm{MPa}$, and 420 530MPa, respectively.

\subsection{Experimental}

Heat affected zone silmulation was carried out using Gleeble 3500 simulator for microstructural observation and Charpy V-notch impact test. Two kinds of thermal cycle simulation were carried out for the evaluation of the effect of peak temperature, and cooling time. The former is the test for simulation of CGHAZ microstructure as a function of a distance from the fusion line. Test materials were heated to various peak temperature of 1200 to $1400{ }^{\circ} \mathrm{C}$ and hold for 5 seconds. The cooling time from 800 to $500^{\circ} \mathrm{C}$ was fixed to 40 seconds. The latter is the test for the effect of heat input on the CGHAZ microstructure. The cooling time from 800 to $500{ }^{\circ} \mathrm{C}$ was changed from 30 to 250 seconds after heated to the peak temperature of $1350^{\circ} \mathrm{C}$ and hold for 5 seconds.

The microstructures and precipitates of simulated specimens were observed using an optical microscope and transmission electron microscope (TEM), respectively. Two kinds of etchants were used for optical microscope, i.e., 4\% nital solution and Le Pera's. The latter one allowed that M-A constituents were distinguished from other phases. TEM micrograph was taken using carbon extraction replicas and thin foiled samples for the quantitative analysis of precipitates and carbides. Charpy V-notch samples were machined and tests were carried out at $-20^{\circ} \mathrm{C}$ in accordance with EN 10045.

Table 1 Chemical composition and tensile properties of test materials

\begin{tabular}{|c|c|c|c|c|c|c|c|}
\hline & $\begin{array}{c}\mathrm{Al} \\
(\mathrm{wt} \%)\end{array}$ & $\begin{array}{c}\mathrm{Si} \\
(\mathrm{wt} \%)\end{array}$ & $\begin{array}{c}\mathrm{Ti} \\
(\mathrm{wt} \%)\end{array}$ & $\begin{array}{c}\mathrm{N} \\
(\mathrm{wt} \%)\end{array}$ & $\begin{array}{c}\text { YS } \\
(\mathrm{MPa})\end{array}$ & $\begin{array}{c}\mathrm{TS} \\
(\mathrm{MPa})\end{array}$ & $\begin{array}{c}\text { EL. } \\
(\%)\end{array}$ \\
\hline 1 & 0.02 & 0.14 & 0.015 & 0.0038 & 330 & 442 & 41.6 \\
\hline 2 & 0.06 & 0.15 & 0.016 & 0.0038 & 327 & 440 & 36.2 \\
\hline 3 & 0.1 & 0.15 & 0.016 & 0.0038 & 325 & 444 & 42.0 \\
\hline 4 & 0.2 & 0.15 & 0.016 & 0.0043 & 334 & 448 & 41.5 \\
\hline 5 & 0.3 & 0.14 & 0.017 & 0.0041 & 331 & 447 & 43.5 \\
\hline 6 & 0.45 & 0.13 & 0.017 & 0.0047 & 325 & 444 & 40.7 \\
\hline 7 & 0.62 & 0.16 & 0.016 & 0.0032 & 335 & 453 & 33.9 \\
\hline 8 & 0.81 & 0.16 & 0.016 & 0.0035 & 334 & 446 & 34.9 \\
\hline 9 & 0.32 & 0.19 & 0.018 & 0.0005 & 333 & 453 & 38.0 \\
\hline 10 & 0.3 & 0.16 & 0.017 & 0.0100 & 292 & 425 & 40.8 \\
\hline 11 & 0.3 & 0.1 & 0.017 & 0.0052 & 411 & 512 & 33.8 \\
\hline 12 & 0.3 & 0.3 & 0.017 & 0.0062 & 378 & 524 & 35.4 \\
\hline
\end{tabular}




\section{Results and discussion}

Fig. 1 shows the effect of aluminum contents on the impact toughness at $-20^{\circ} \mathrm{C}$ of the simulated CGHAZ as a function of (a) peak temperatures and (b) cooling time. As shown in Fig. 1a, the impact toughness was gradually increased as aluminum contents increase from 0.02 to $0.3 \mathrm{wt} \%$. The drastic decrease of impact toughness with increase of the peak temperature above $1350^{\circ} \mathrm{C}$ was not observed with the aluminum contents above $0.3 \mathrm{wt} \%$. The impact toughness was slightly decreased with higher aluminum content of $0.45 \mathrm{wt} \%$. When aluminum content was increased above $0.6 \mathrm{wt} \%$, impact toughness was dramatically decreased at overall peak temperature. In the same manner, when the cooling time from 800 to $500^{\circ} \mathrm{C}$ was changed from 80 to 250 seconds with the fixed peak temperature of $1350^{\circ} \mathrm{C}$ (Fig. 1b), the impact toughness was highly maintained with the aluminum content of 0.1 to $0.45 \mathrm{wt} \%$. The toughness of 0.02 and $0.06 \mathrm{wt} \%$ aluminum added material was gradually decreased with increase of cooling time while 0.6 and $0.8 \mathrm{wt} \%$ aluminum added materials show the extremely low impact toughness throughout the entire

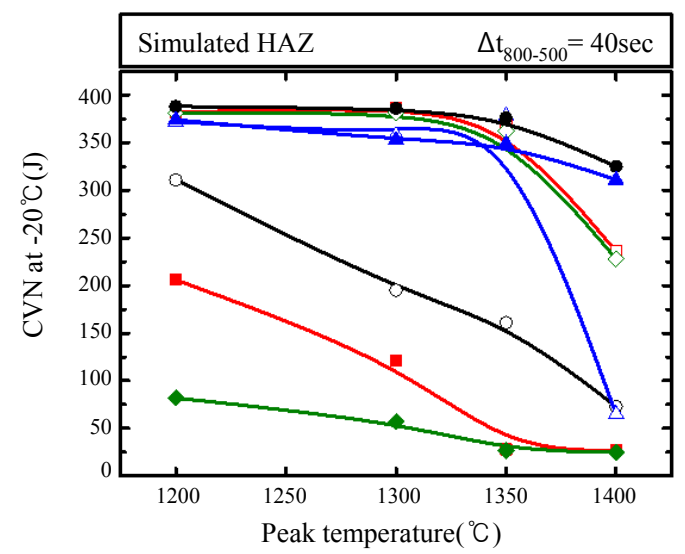

(a) range of cooling time. As a result of the charpy impact tests, it could be concluded that impact toughness of simulated CGHAZ was increased with the appropriate aluminum contents in the range of 0.1 to $0.45 \mathrm{wt} \%$.

Fig. 2 shows the CGHAZ microstructures simulated with the peak temperature of $1400^{\circ} \mathrm{C}$ and cooling time from 800 to $500^{\circ} \mathrm{C}$ of 40 seconds. The simulated microstructures with the different aluminum content were primarily consist of bainite and ferrite. The fraction of pro eutectoid grain boundary ferrite was increased while the fraction of bainite was decreased as aluminum content increases from $0.02 \mathrm{wt} \%$ up to $0.45 \mathrm{wt} \%$, as shown in Fig. 2a through $2 \mathrm{f}$. It could be concluded that the ferrite transformation is promoted by the accelerated ferrite nucleation as a result of the addition of ferrite stabilizer, aluminum ${ }^{7,8)}$. The increase of the start temperature of ferrite transformation with higher aluminum content was also observed by a series of additional dilatation test. However, the ferrite fractions in microstructures with higher aluminum content of 0.6 and $0.8 \mathrm{wt} \%$ were remarkably decreased while the fraction of bainite was increased as shown in Figs. $2 \mathrm{~g}$ and $2 \mathrm{~h}$.

The CGHAZs simulated with the peak temperature of

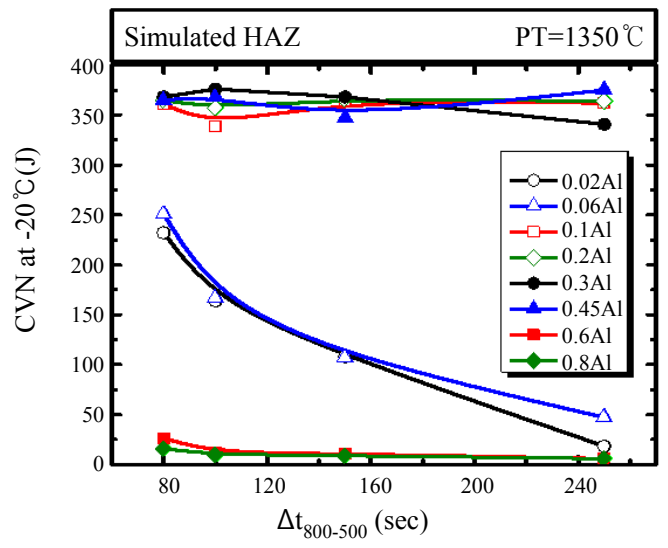

(b)

Fig. 1 Impact toughness of simulated HAZ of various $\mathrm{Al}$ added steels as a function of (a) peak temperature, (b) $\Delta \mathrm{t}{ }_{800-500}$
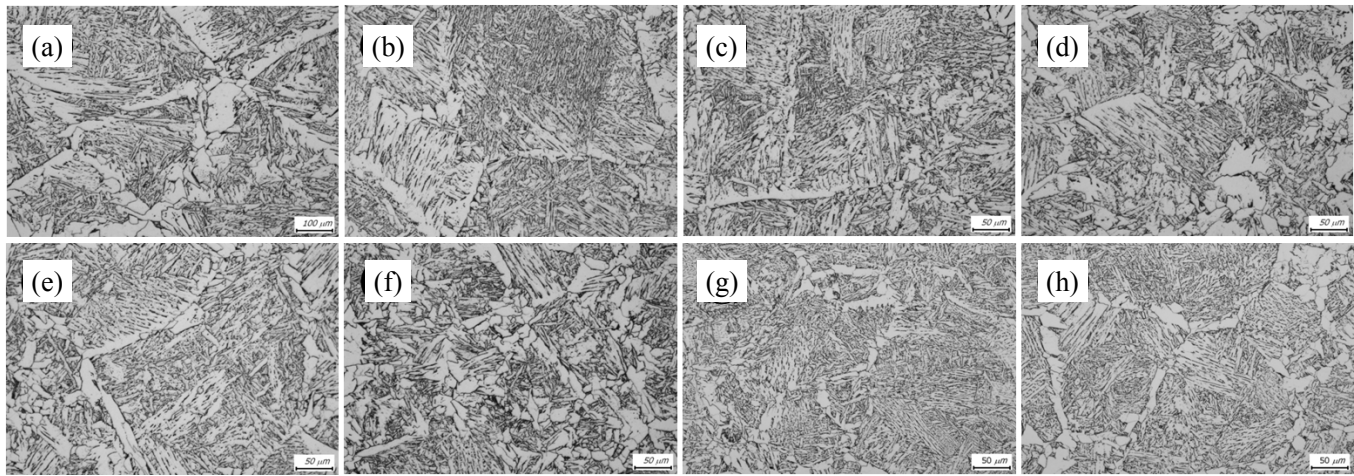

Fig. 2 Microstructures of simulated heat affected zone (peak temp: $1400^{\circ} \mathrm{C}, \Delta \mathrm{t}{ }_{800-500}=40 \mathrm{sec}$ ) with different $\mathrm{Al}$ contents(wt\%), (a) 0.02, (b) 0.06, (c) 0.1, (d) 0.2, (e) 0.3, (f) 0.45, (g) 0.6, (h) 0.8 
$1350{ }^{\circ} \mathrm{C}$ and cooling time from 800 to $500^{\circ} \mathrm{C}$ of $100 \mathrm{sec}-$ onds (Fig. 3) show the similar manner in microstructural changes as aluminum contents increase compare to the case of shorter cooling time, 40 seconds (Fig. 2). The ferrite fraction increases and bainite fraction decreases as $\mathrm{Al}$ content increases up to $0.45 \mathrm{wt} \%$ (Fig. 3a through 3f). The size and fraction of ferrite in Fig. 3 was bigger than Fig. 2 due to the extended cooling time that allows the increase of transformation start temperature, nucleation, and growth of the ferrite. When the $\mathrm{Al}$ content were increased over $0.6 \mathrm{wt} \%$ (Figs. $3 g$, 3f), the ferrite fraction was decreased and bainite fraction was increased remarkably, similar to Figs. $2 \mathrm{~g}$ and $2 \mathrm{~h}$.

Palizdar $^{7)}$ reported the effect of $\mathrm{Al}$ addition on the microstructure of $0.02 \mathrm{C}-0.3 \mathrm{Si}-1.4 \mathrm{Mn}-0.001 \mathrm{~N}-(0.02 \sim 0.9)$ $\mathrm{Al}$ steels and observed the grain size refinement when the $\mathrm{Al}$ content was increased above $0.48 \mathrm{wt} \%$. He pointed out that there are two reasons for grain refinement with the $\mathrm{Al}$ contents above $0.48 \mathrm{wt} \%$ as follows. The first is the pinning effect and austenite grain growth re- tardation by AIN precipitates that allow the ferrite grain refinement. However, this cannot be completely applicable in the present study due to the different kind of primary precipitates involved in the Ti-added steels used in this study. Fig. 4 shows the typical TEM micrograph from a carbon extraction replica and an energy probe $\mathrm{x}$-ray micro analysis (EPMA) for a precipitate in the CGHAZ of $0.6 \mathrm{Al}$ added steel that was simulated with the peak temperature of $1400^{\circ} \mathrm{C}$ and 40 seconds of the cooling time from 800 to $500^{\circ} \mathrm{C}$. It has been revealed that the primary precipitates were $\mathrm{TiN}$, and the secondary AlN and CuS were attached to the primary precipitate. The precipitation temperatures of TiN and AlN were above $1420^{\circ} \mathrm{C}$, and near at $1100^{\circ} \mathrm{C}$, respectively as a result of thermodynamic calculation. Therefore, the formation mechanism of the precipitates in Fig. 4 could be explained as an agglomeration of each precipitate which has different temperature of precipitation. In short, TiN is the primary precipitate which affects the refinement of austenite grain rather than AIN in the

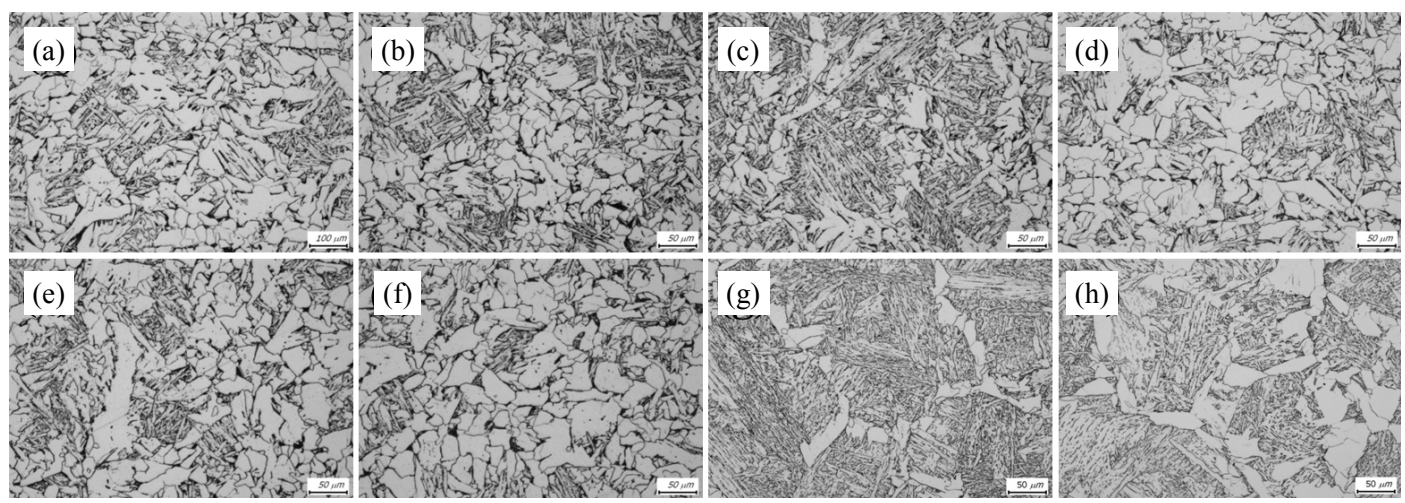

Fig. 3 Microstructures of simulated heat affected zone (peak temp: $1350^{\circ} \mathrm{C}, \Delta \mathrm{t}{ }_{800-500}=100 \mathrm{sec}$ ) with different $\mathrm{Al}$ contents(wt\%), (a) 0.02, (b) 0.06, (c) 0.1, (d) 0.2, (e) 0.3, (f) 0.45, (g) 0.6, (h) 0.8
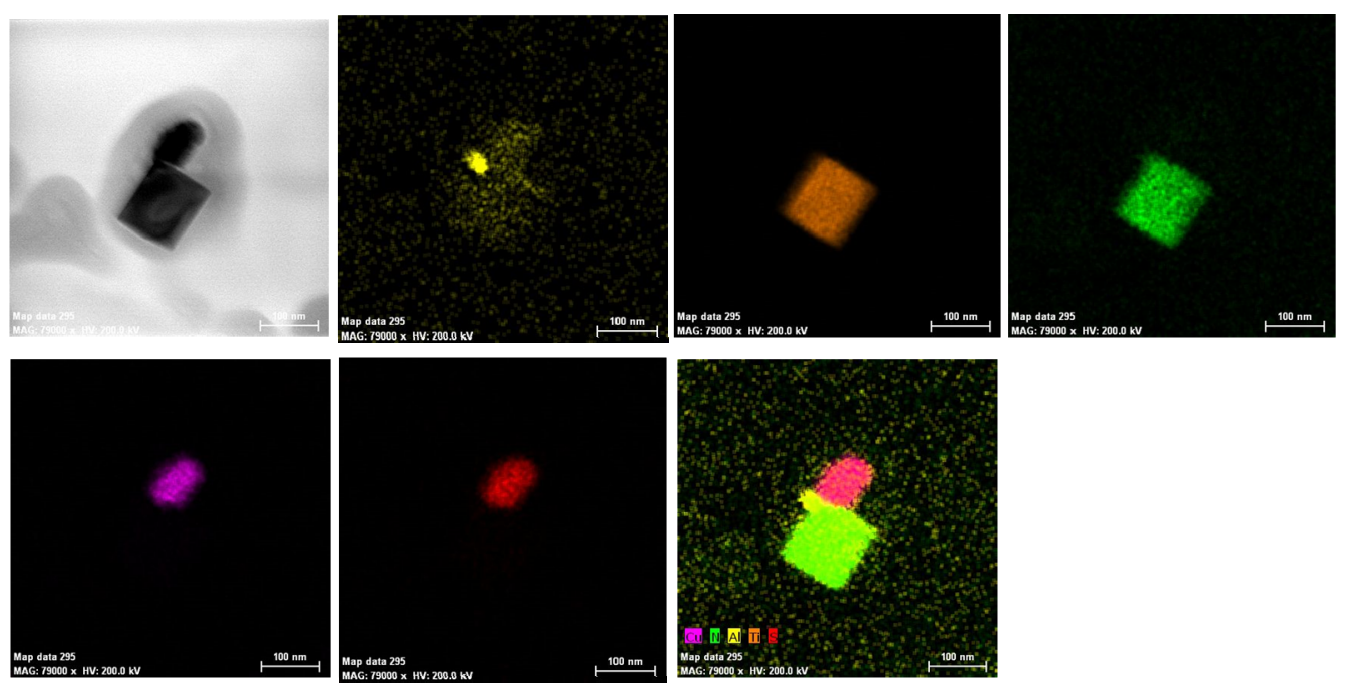

Fig. 4 Typical precipitates in simulated heat affected zone of $0.6 \mathrm{Al}$ added steel 
CGHAZ of the steels used in this study. The second potential explanation for grain refinement with $\mathrm{Al}$ addition is segregation of $\mathrm{Al}$ at ferrite/austenite interfaces that could allow the retardation of ferrite growth, resulting in fine grain size. As shown in Figs. 2g, 2h, 3g, and 3h, the ferrite fraction of the CGHAZ was dramatically decreased above the $\mathrm{Al}$ content of $0.45 \mathrm{wt} \%$ similar to Palizdar's results of grain refinement when the $\mathrm{Al}$ content was increased over $0.48 \mathrm{wt} \%$ while the quantity of AlN was almost fixed. It could be concluded that the drastic decrease of toughness of the CGHAZ with high Al content of 0.6 and $0.8 \mathrm{wt} \%$ was due to the decrease of ferrite and increase of brittle bainite caused by $\mathrm{Al}$ partitioning at ferrite/austenite interface.

Mintz $^{6}$ reported that the quantity and size of carbide could be diminished by $0.2 \sim 0.9 \mathrm{wt} \% \mathrm{Al}$ addition due to lower diffusivity of carbon in $(0.02,0.1 \% \mathrm{C})-(10,40 \mathrm{ppm}$ N) steel resulting in increase of HAZ toughness. Fig. 5 shows the TEM micrograph and carbon profile in the CGHAZ of 0.03 and $0.3 \mathrm{wt} \% \mathrm{Al}$ added steels simulated with the peak temperature of $1400^{\circ} \mathrm{C}$ and cooling time from 800 to $500^{\circ} \mathrm{C}$ of 40 seconds. The finer and less quantity of cementite were observed in the $0.3 \mathrm{wt} \% \mathrm{Al}$ added steel $(1.3 \%$ of the volume fraction in Fig. $5 \mathrm{c})$ compare to the $0.03 \mathrm{wt} \% \mathrm{Al}$ added steel $(0.3 \%$ of the volume fraction in Fig. 5a). Table 2 shows the results of extracted residue analysis of 0.03 and $03 \mathrm{wt} \% \mathrm{Al}$ added CGHAZ in Fig. 5. The extraction ratio was decreased remarkably from 37 to $6.2 \%$ when the $\mathrm{Al}$ content was increased from 0.03 to $0.3 \mathrm{wt} \%$, while $\mathrm{Al}$ was almost remained as solid solution in matrix. The quantity of $\mathrm{Fe}$ in residue was decreased from 2.95 to $2.23 \%$ as $\mathrm{Al}$ was increased from 0.03 to $0.3 \mathrm{wt} \%$. If the Fe contained precipitate is assumed to one hundred percent of cementite, the carbon content in cementite can be decreased from 0.21 to $0.16 \%$. Therefore, it could be concluded that $\mathrm{Al}$ suppress the carbon diffusivity resulting in decrease of cementite precipitation.

Meanwhile, high free or solid solutioned aluminum in steel has been found to enhance the formation of M-A constituent $^{9)}$. In the viewpoint of cementite precipitation, the effect of $\mathrm{Al}$ on preventing diffusion of car-
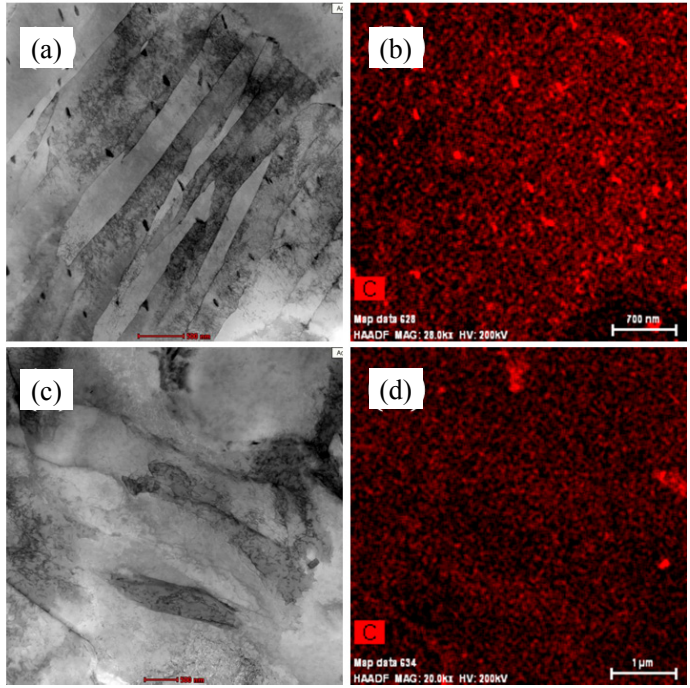

Fig. 5 Carbide distribution in simulated heat affected zone. (a) and (b)TEM micrograph and carbon profile in $0.03 \% \mathrm{Al}$ containing steel, respectively. (c) and (d) TEM micrograph and carbon profile in $0.3 \% \mathrm{Al}$ containing steel, respectively

Table 2 Results of extraction residue analysis of simulated heat affected zone

\begin{tabular}{|c|c|c|c|c|c|}
\hline & $\begin{array}{c}\mathrm{Al}(\%) \\
\text { in matrix }\end{array}$ & $\begin{array}{c}\mathrm{Al}(\%) \\
\text { in residue }\end{array}$ & $\begin{array}{c}\text { Extraction } \\
\text { ratio(\%) }\end{array}$ & $\begin{array}{c}\mathrm{Fe}(\%) \\
\text { in residue }\end{array}$ & $\begin{array}{c}\mathrm{C}(\%) \\
\text { in } \mathrm{Fe}_{3} \mathrm{C}\end{array}$ \\
\hline $0.03 \mathrm{Al}$ & 0.026 & 0.01 & 37 & 2.95 & 0.21 \\
\hline $0.3 \mathrm{Al}$ & 0.3 & 0.002 & 6.2 & 2.23 & 0.16 \\
\hline
\end{tabular}

bon is advantage, but it could encourage the formation of M-A constituent, one of the most harmful element to toughness. M-A constituent is formed from carbon enriched austenite by the retardation of the transformation from austenite to ferrite and cementite during cooling ${ }^{10}$ due to an excess of $\mathrm{Al}$ partition in proeutectoid ferrite and bainite. Figs. 6a, 6b, 6c show the M-A constituent distribution in the CGHAZ simulated with the peak temperature of $1400{ }^{\circ} \mathrm{C}$ and 40 seconds of the cooling time from 800 to $500^{\circ} \mathrm{C}$. The volume fractions of M-A constituents were $0.63,0.70$, and $1.03 \%$ for $0.02 \mathrm{wt} \%$ (Fig. 6a), $0.1 \mathrm{wt} \%$ (Fig. 6b), and $0.3 \mathrm{wt} \%$ (Fg.6c) of $\mathrm{Al}$,
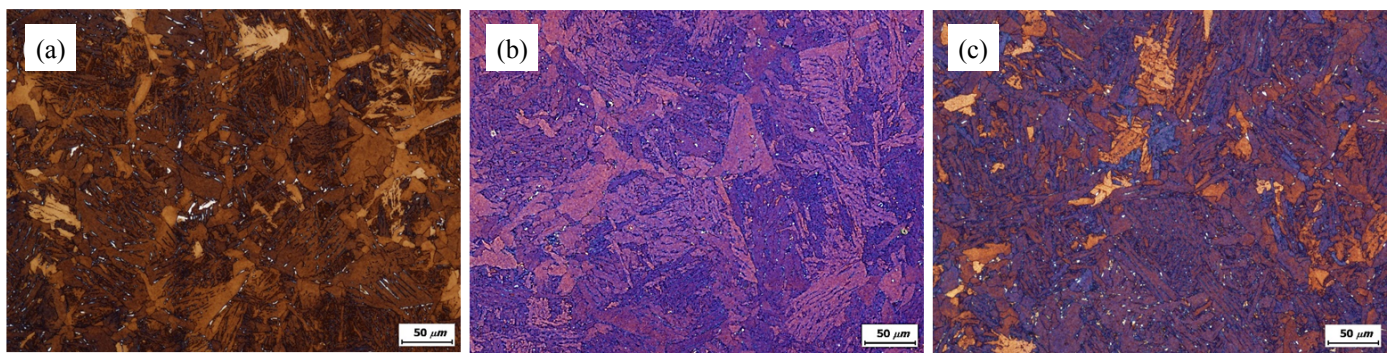

Fig. 6 M-A constituents distribution of simulated heat affected zone (peak temp: $1400{ }^{\circ} \mathrm{C}, \Delta \mathrm{t}{ }_{800-500}=40 \mathrm{sec}$ ) with different $\mathrm{Al}$ contents(wt\%), (a) 0.02 , (b) 0.1 , (c) 0.3 
respectively. The more $\mathrm{Al}$ contents, the higher area fraction of M-A constituent was observed, but it is important to note that the area fraction of M-A constituent was not too high below $2.0 \%$ and no massive type constituent was observed throughout all of the specimens in the condition of same CGHAZ simulation schedule.

Figs. $7 \mathrm{a}$ and $7 \mathrm{~b}$ show the effect of nitrogen content on the impact toughness at $-20^{\circ} \mathrm{C}$ of the simulated CGHAZ as a function of (a) peak temperatures and (b) cooling time from 800 to $500^{\circ} \mathrm{C} .5,41$, and $100 \mathrm{ppm}$ of nitrogen were added to $0.3 \mathrm{wt} \% \mathrm{Al}$ steels (No. 9, 5, 10 specimens in Table 1). The impact toughness of the 5 ppm $\mathrm{N}$ added steel was gradually decreased as a peak temperature was increased while the toughness of 41 and 100ppm nitrogen added steel was maintained above 250J (Fig. $7 \mathrm{a}$. In the same manner, the impact toughness of the 5 ppm $\mathrm{N}$ added steel was gradually decreased as a cooling time was increased as shown in Fig. $7 \mathrm{~b}$. The $41 \mathrm{ppm}$ of nitrogen added steel shows the highest impact value throughout all over the test condition while 5 ppm of nitrogen added steel shows the lowest. Impact toughness of $100 \mathrm{ppm}$ of nitrogen added steel was lower than that of the $41 \mathrm{ppm}$ of nitrogen added steel, and the gap of value was about $100 \mathrm{~J}$. The difference of the impact toughness value as a function of the $\mathrm{N}$ content could be explained by the stability of TiN at high temperature and following austenite grain size near to the fusion line. The Ti to $\mathrm{N}$ ratio of 5, 41, 100ppm of nitrogen added steels are 36, 4.14, and 1.7, respectively. Therefore, it could be assumed that the thermal stability of the TiN is in following order, 100, 41, and $5 \mathrm{ppm}$ of nitrogen added steels in the condition of almost same Ti content ${ }^{11)}$. As shown in Fig. 8, the more $\mathrm{N}$ content, the more proeutectoid ferrite was formed while bainite fraction was

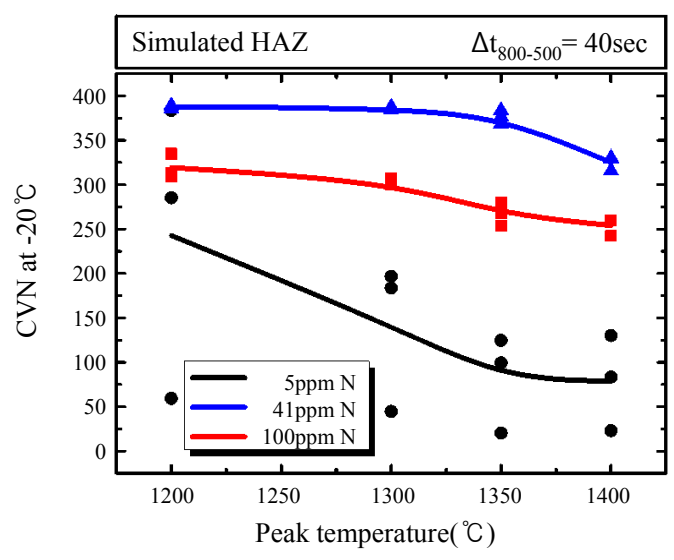

(a)

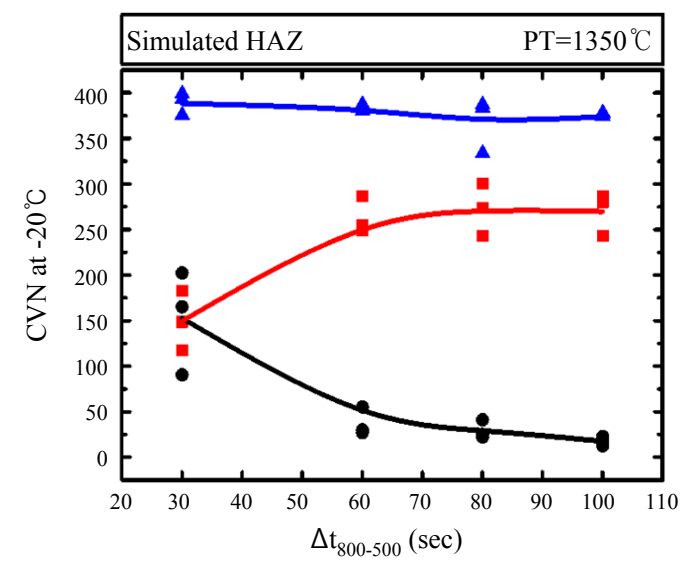

(b)

Fig. 7 Impact toughness of simulated HAZ with the different nitrogen contents, 5, 41, 100ppm as a function of (a) peak temperature, (b) $\Delta \mathrm{t}_{800-500}$
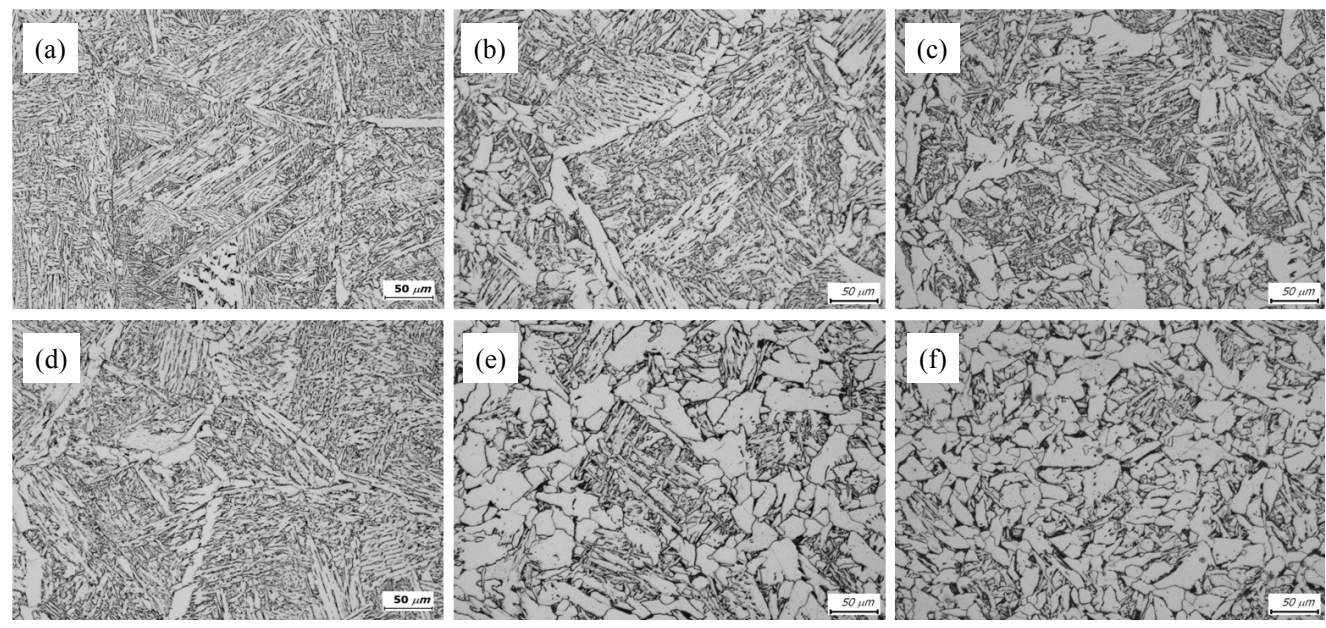

Fig. 8 Microstructures of simulated heat affected zone, (a), (b), (c) peak temp: $1400{ }^{\circ} \mathrm{C}, \Delta \mathrm{t} 800-500=40 \mathrm{sec},(\mathrm{d})$, (e), (f) peak temp: $1350^{\circ} \mathrm{C}, \Delta \mathrm{t}{ }_{800-500}=100 \mathrm{sec}$ with the different nitrogen contents, $5 \mathrm{ppm}$ for (a), (d), $41 \mathrm{ppm}$ for (b), (e), $100 \mathrm{ppm}$ for (c) and (f) 


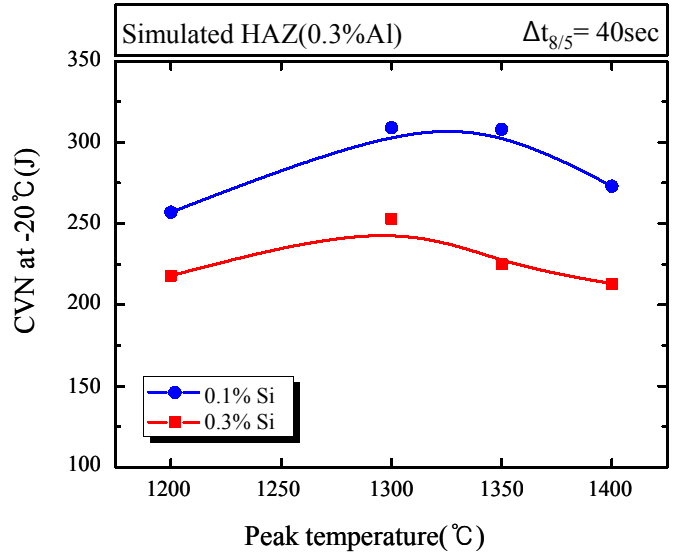

(a)

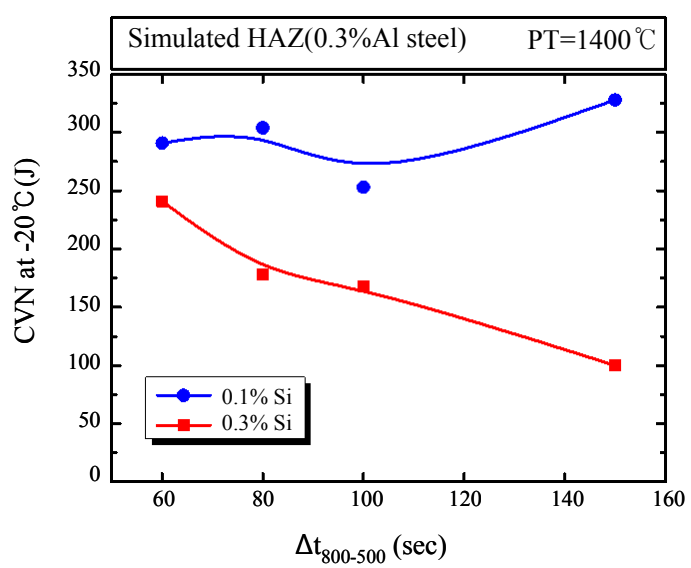

(b)

Fig. 9 Impact toughness of simulated HAZ with 0.1 and $0.3 \mathrm{wt} \% \mathrm{Si}$ as a function of (a) peak temperature, (b) $\Delta t{ }_{800-500}$

decreased. The more ferrite was formed as cooling time increased from 40 to 100 seconds in the temperature range of 800 to $500^{\circ} \mathrm{C}$ in comparison with Figs. 8a through $8 \mathrm{c}$ and $8 \mathrm{~d}$ through $8 \mathrm{f}$. In case of the lowest, $5 \mathrm{ppm}$ of nitrogen added specimen, bainite fraction was highest due to the largest prior austenite grain size as shown in Figs. 8a, 8d. In addition, it could be concluded that lower toughness of $100 \mathrm{ppm}$ nitrogen added steel than $41 \mathrm{ppm}$ added steel was due to the excessive ferrite fraction and free $\mathrm{N}$.

Figs. $9 a$ and $9 b$ show the effect of 0.1 and $0.3 w t \%$ of silicon contents on the impact toughness of the simulated CGHAZ of $0.3 \mathrm{wt} \% \mathrm{Al}$ added steels as a function of (a) peak temperatures and (b) cooling time from 800 to $500^{\circ} \mathrm{C}$ (No. 11, 12 specimens in Table 1). As shown in the Figs, the impact toughness of $0.3 \mathrm{wt} \% \mathrm{Si}$ added steels were lower than $0.1 \mathrm{wt} \% \mathrm{Si}$ added steels in the entire range of peak temperature and cooling time. Fig. 10 shows the microstructure of simulated HAZ as a function of Si content and the peak temperature with the cooling time from 800 to $500^{\circ} \mathrm{C}$ of 40 seconds for (a) $0.1 \mathrm{wt} \%, 1350^{\circ} \mathrm{C}$, (b) $0.3 \mathrm{wt} \%, 1350^{\circ} \mathrm{C}$, (c) $0.1 \mathrm{wt} \%, 1400^{\circ} \mathrm{C}$, (d) $0.3 \mathrm{wt} \%, 1400^{\circ} \mathrm{C}$ of Si content and the peak temperature, respectively. The less ferrite and more bainite were observed in $0.3 \mathrm{wt} \%$ compare to $0.1 \mathrm{wt} \%$ of $\mathrm{Si}$ added steel due to higher carbon equivalent. Besides the higher bainite fraction, the fraction of M-A constituent was another important factor which could determine the lower impact toughness of $0.3 \mathrm{wt} \%$ of $\mathrm{Si}$ added steel CGHAZ. M-A constituent is promoted by $\mathrm{Si}$ addition due to the retardation effect of cementite precipitation resulting in carbon enrichment in austenite ${ }^{9,12)}$. As shown in Fig. 11, more and bigger M-A constituent was observed in $0.3 \mathrm{wt} \%$ of $\mathrm{Si}$ added steel $(1.98 \%$ of the volume fraction in Fig. 11a) compare to $0.1 \mathrm{wt} \%$ of $\mathrm{Si}$ added steel $(0.54 \%$ of the volume fraction in Fig. $11 \mathrm{~b})$. In summary, it is important to determine the appropriate $\mathrm{Si}$
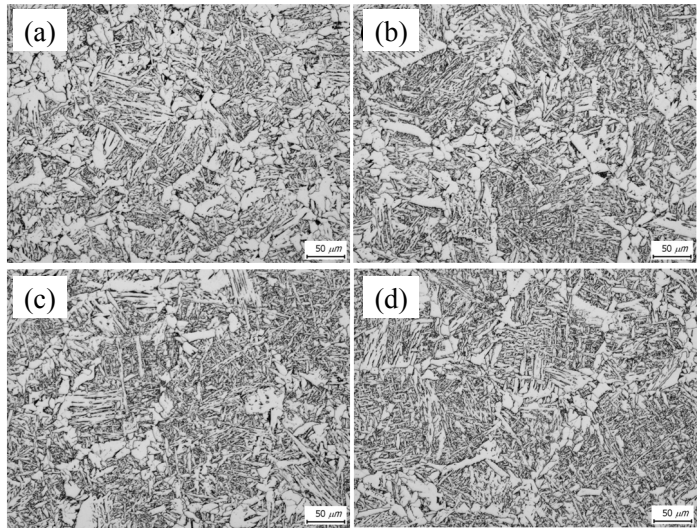

Fig. 10 Microstructures of simulated heat affected zone as a function of Si content and the peak temperature with the cooling time from 800 to $500^{\circ} \mathrm{C}$ of 40seconds for (a) $0.1 \mathrm{wt} \% \mathrm{Si}$, peak temp.: $1350{ }^{\circ} \mathrm{C}$, (b): $0.3 \mathrm{wt} \% \mathrm{Si}$, peak temp.: $1350^{\circ} \mathrm{C}$, (c) $0.1 \mathrm{wt} \% \mathrm{Si}$, peak temp.: $1400^{\circ} \mathrm{C}$, (d) $0.3 \mathrm{wt} \% \mathrm{Si}$, peak temp.: $1400^{\circ} \mathrm{C}$
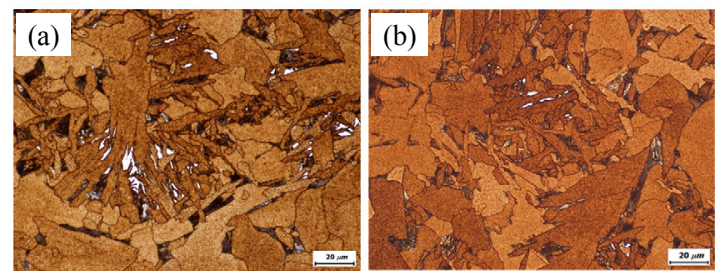

Fig. $11 \mathrm{M}-\mathrm{A}$ constituent in the simulated heat affected zone with the peak temperature of $1350{ }^{\circ} \mathrm{C}$ and the cooling time of 40 seconds from 800 to $500^{\circ} \mathrm{C}$ : (a) $0.3 \mathrm{Al}-0.3 \mathrm{Si}$, (b) $0.3 \mathrm{Al}-0.1 \mathrm{Si}$

content concerning strength and toughness of the $\mathrm{Al}$ added steels.

\section{Conclusion}

The effect of Al, N, and Si content on the toughness of 
the simulated CGHAZ of tensile strength, 400-500MPa grade C-Mn steel was investigated. Main results obtained are as follows.

The impact toughness of simulated CGHAZ was increased with aluminum content in the range of 0.1 to $0.45 \mathrm{wt} \%$ due to the appropriate phase fraction of ferrite and bainite, less cementite with no massive and little quantity of M-A constituent.

In the viewpoint of $\mathrm{TiN}$ precipitation, nitrogen content should be maintained at the value near to the stoichiometric ratio of $\mathrm{Ti} / \mathrm{N}$ to avoid undesirable austenite grain growth with small $\mathrm{N}$ content, and an excessive ferrite fraction, a free nitrogen with too much $\mathrm{N}$ content.

Si content should be maintained concerning strength and toughness of the Al added steels, especially for avoiding additional formation of M-A constituent.

ORCID: Hongchul Jeong: https://orcid.org/0000-0002-2051-9438 ORCID: Kyutae Han: https://orcid.org/0000-0002-9561-2004

\section{References}

1. Y. Fukada and Y. Komizo, Effect of Al content on critical CTOD properties in heat affected zones of C-Mn microalloyed steel, Weld. Int. 7 (4) (1993), 286-291. https://doi.org/10.1080/09507119309548391

2. H. Xue and T. N. Baker, Influence of aluminum on carbide precipitation in low carbon microalloyed steels, Mater. Sci. Tech. 9 (5) (1993), 424-429. https://doi.org/10.1179/mst.1993.9.5.424

3. L. Yu, H. Wang, X. Wang, G. Huang, T. Hou, K. Wu, Improvement of impact toughness of simulated heat affected zone by addition of aluminum, Mater. Sci. Tech. 30 (15) (2014), 1951-1958. https://doi.org/ 10.1179/1743284714Y.0000000602

4. K.Nishio, Ph.D. thesis, $40 \mathrm{Kgf} / \mathrm{mm} 2$ 級鋼の溶接熱影 響部のミクロ組織と切欠勒性に及ぼす微量添加元 素の影響に關する研究, Osaka Univ., Osaka, Japan (1985) 117.
5. I. Watanabe, High Al-low N -micro Ti type C-Mn steels developed to enhance weldment reliability, The Fourth International Symposium of Japan Welding Society, Osaka, Japan (1982).

6. B. Mintz, W. Gunawardana, H. Su, Influence of $\mathrm{Al}$ on strength and impact behaviour of hot rolled plain C-Mn steels, Mater. Sci. Tech. 24 (5) (2008), 601-606. https://doi.org/10.1179/174328408X284478

7. Y. Palizdar, A. Scott, R. Cochrane, R. Brydson, Mat. Sci. Tech., Understanding the effect of aluminium on microstructure in low level nitrogen steels, Mater. Sci. tech. 25 (10) (2009), 1243-1248. https://doi.org/10.1179/174328409X401133

8. M. Eldridge, R. Cochrane, The Influence of Aluminium and Silicon on Transformation Kinetics in Low Alloy Steels, Mat. Sci. Forum. 284-286 (1998), 217-224. https://doi.org/10.4028/www.scientific.net/MSF.284-286. 217

9. F. Matsuda, Y. Fukada, H. Okada, Review of mechanical and metallurgical investigations of martensite-austenite constituent in welded joints in Japan, Weld. World. 37 (3) (1996), 134-154.

10. P. Rodrigues, E. Pereloma, D. Santos, Mechanical properties of an HSLA bainitic steel subjected to controlled rolling with accelerated cooling, Mat. Sci. Eng. A-Struct. 283 (2000), 136-143. https://doi.org/10.1016/S0921-5093(99)00795-9

11. K. Inoue, I. Ohnuma, H. Ohtani, K. Ishida, T. Nishizawa, Solubility product of TiN in austenite, ISIJ Int. 38 (1998), 991-997.

https://doi.org/10.2355/isijinternational.38.991

12. D. Fairchild, N. Bangary, J. Koo, P. Harrisson, A. Ozakcin, A study concerning intercritical HAZ microstructure and toughness in HSLA steels, Weld. J. 70 (1991) 321s-329s. 